\title{
The Effect of Motivational Interviewing on Adolescent Risk Behaviors: A Literature Review
}

\author{
Eka Retno Wulandari, Linlin Lindayani*, and Herdiman Herdiman \\ STIKep PPNI Jawa Barat
}

\section{ORCID}

Linlin Lindayani: https://orcid.org/0000-0002-1569-4098

Corresponding Author: Linlin Lindayani; email:

linlinlindayani@gmail.com

Published: 7 February 2022

Publishing services provided by Knowledge E

(c) Eka Retno Wulandari et al. This article is distributed under the terms of the Commons Attribution License, which permits unrestricted use and redistribution provided that the original author and source are credited.

Selection and Peer-review under the responsibility of the IVCN Conference Committee.
Abstract. Motivational interviewing is a client-centered counseling method that is used to promote behavior change by eliciting client motivations for change and analyzing conflicting client motivations. The purpose of this literature review was to summarize the effect of motivational interviewing on adolescent risk behaviors. Articles published in English between 2015-2020 were searched in MEDLINE, CINAHL, and the Cochrane Library. The reviewers extracted and summarized the data using the Joanna Briggs Institute ( JBI) data extraction tool. A total of six articles were included in this review. It can be concluded from the results that counseling combined with motivational interviewing is beneficial at reducing risky sexual behavior in teenagers and in preventing HIV transmission.

Keywords: adolescent, motivational interviewing, risk behaviors, review

\section{Introduction}

Motivational interviewing is a client-centered counseling method that has been successfully utilized to promote behavior change by eliciting client motivations for change and analyzing conflicted client motivations [1]. Motivational interviewing is a brief intervention that is used to address a variety of health behavior issues [2]. The study's findings imply that motivational interviewing is an excellent tool for addressing teenagers' unique issues, such as the need for self-determination and increasing autonomy [3]. [4] research in the United States of America demonstrates that motivational interviewing interventions can considerably reduce risky sexual behavior and boost condom use [4]. Although motivational interviewing is considered easier to utilize than didactic educational counseling, the intervention has a significant effect, indicating that motivational interviewing can help reduce unprotected sex among research participants [5].

Several previous research found that this motivational interviewing-based intervention was most effective at overcoming smoking and alcohol use problems. Additionally, research on motivational interviewing with an emphasis on sexual behavior and life skills 
is still in its infancy and is conducted seldom. Motivational interviewing has been demonstrated to be effective in reducing drug use and improving sexual health in adolescents, particularly sexual minority adolescents. The researchers discovered empirical support for the Young Men Health Project (YMPH), a four-session motivational interview-based intervention designed to reduce drug use and risk behaviors for HIV transmission [6]. Because the use of change talk is one of motivational interviewing's strengths, when OARS is used to induce change talk, clients see more behavioral changes. Someone influential can have an effect on the client's transformation conversation. In one study, participants whose significant others engaged in supportive discourse were more likely to make their own positive change statements and actually achieve greater degrees of behavioral change [7]. The purpose of this review was to summarized the effect of motivational interviewing on adolescence risk behaviors.

\section{Methods}

A review was used to examine the efficacy of motivational interviewing on adolescence risk behaviors in this study.

\subsection{Strategy for Search}

The purpose of the search approach was to find research that had already been published. A preliminary search of MEDLINE, CINAHL, and the Cochrane Library was followed by a review of the title, abstract, and index keywords used to characterize the paper. The articles covered in this evaluation were those that were published in English between the years 2015 and 2020. We began by selecting keywords from the MeSH database that included the following terms: motivational interviewing OR counseling AND adolescent or teenager or youth AND risk behaviors OR homosexuality OR substance abuse.

\subsection{Criteria for Inclusion}

The quantitative section of this review included studies examining the effect of motivational interviewing on teenage risk behaviors. Adolescents and those under the age of 18 were included. Randomized controlled trials, non-randomized controlled trials, quasi experimental studies, before and after studies, and prospective and retrospective 
cohort studies were inclusion criteria. Adolescence risk behaviors including sexual risk behavior, drug use, and alcohol use.

\subsection{Extraction of data}

The reviewers extracted and summarized data using the Joanna Briggs Institute (JBI) data extraction tool. Participants' demographics, sample inclusion and exclusion criteria, study setting, number and reasons for withdrawal from study, type and description of motivational interviewing intervention, application and follow up of intervention, measure of outcomes, statistical methods, and study outcome descriptions are among the data collected.

\subsection{Methodological quality assessment}

The Appraisal tool from the JBI was used to assess methodological validity. All papers chosen for inclusion underwent a rigorous, independent evaluation to identify and choose papers of the highest quality, with the exception of those that minimize bias and have good validity and accuracy. According to expert opinion, either bench research or consensus has been reached.

\section{Results}

\subsection{Searching results}

The literature searches generated 213 studies through searches of databases, excluding duplicates. From above number, we excluded the studies that were not included motivational interviewing and adolescence risk behaviors. A total of 6 articles included in this review.

\subsection{Summary of results}

The characteristics of included studies was shown in Table 1.

The use of condoms during anal sex was increased in China for men who had sex with men after a four-week motivational interviewing intervention [8]. In the control group, the average HIV knowledge score was six $=(S D=2)$, but in the intervention group, the average score was seven $(\mathrm{SD}=2)[8]$ 
TABLE 1: Characteristics of included studies

\begin{tabular}{|c|c|c|c|c|c|}
\hline $\begin{array}{l}\text { Authors, } \\
\text { years, } \\
\text { country }\end{array}$ & Study design & Sample & Intervention & Instrument & results \\
\hline $\begin{array}{l}\text { J.Chen et } \\
\text { al, } 2016 \text {, } \\
\text { China. }\end{array}$ & $\begin{array}{l}\text { Quasi- } \\
\text { experiment } \\
\text { with pre } \\
\text { and post } \\
\text { intervention. }\end{array}$ & $\begin{array}{l}\mathrm{N}=120 \\
\text { participants }\end{array}$ & $\begin{array}{l}\text { The motivational inter- } \\
\text { viewing intervention was } \\
\text { carried out for four ses- } \\
\text { sions. Each session aver- } \\
\text { ages about } 60 \text { minutes. } \\
\text { Ml intervention uses core } \\
\text { skills, namely open ques- } \\
\text { tions, affirmations, reflec- } \\
\text { tions, and summary. }\end{array}$ & $\begin{array}{l}\text { sexual } \\
\text { behavior }\end{array}$ & $\begin{array}{l}\text { The motivational } \\
\text { interviewing } \\
\text { intervention could } \\
\text { be carried out and } \\
\text { resulted in increased } \\
\text { use of condoms } \\
\text { during anal sex for } \\
\text { men. HIV knowledge } \\
\text { scores increased } \\
\text { from baseline to } \\
\text { post-intervention in } \\
\text { both groups, but the } \\
\text { increase was not } \\
\text { statistically significant } \\
(P=0.06) \text {. }\end{array}$ \\
\hline $\begin{array}{l}\text { P. Monti } \\
\text { et al, } \\
2016, \\
\text { Amerika. }\end{array}$ & $\begin{array}{l}\text { Randomized } \\
\text { Controll Trial. }\end{array}$ & $N=184$ & $\begin{array}{l}\text { The one-session } \\
\text { Motivational Interviewing } \\
\text { manual incorporates } \\
\text { an open exploration of } \\
\text { the pros and cons of } \\
\text { drinking, personalized } \\
\text { and printed graphic } \\
\text { feedback of alcohol } \\
\text { use and consequences } \\
\text { assessment, normative } \\
\text { comparisons, } \\
\text { discussion of use and } \\
\text { consequences, } \\
\text { sexual risk behaviors } \\
\text { including engaging in } \\
\text { multiple partner sex and } \\
\text { sex. without a condom. }\end{array}$ & $\begin{array}{l}\text { Alcohol Use } \\
\text { and Sexual } \\
\text { Behavior } \\
\text { (TLFB-SS) }\end{array}$ & $\begin{array}{l}\text { Decreased alcohol use } \\
\text { and sexual behavior }\end{array}$ \\
\hline $\begin{array}{l}\text { Melanie } \\
\text { A.Gold et } \\
\text { al, 2016, } \\
\text { Amerika. }\end{array}$ & $\begin{array}{l}\text { Random Con- } \\
\text { troll Trials. }\end{array}$ & $\begin{array}{l}\mathrm{N}=572 \\
\text { female } \\
\text { adolescents } \\
\text { with an } \\
\text { average age } \\
\text { of } 17 \text { years } \\
\text { who are } \\
\text { at risk of } \\
\text { pregnancy } \\
\text { and sexually } \\
\text { transmitted } \\
\text { diseases. }\end{array}$ & $\begin{array}{l}\text { Counselor-Guided } \\
\text { Motivational Intervention } \\
\text { (CAMI) on the basis of the } \\
\text { conceptual framework of } \\
\text { TTM and the use of MI } \\
\text { as a counseling strategy } \\
\text { compared with didactic } \\
\text { education counseling } \\
\text { (DEC) to reduce STD and } \\
\text { pregnancy risk behaviors } \\
\text { among adolescent girls. }\end{array}$ & $\begin{array}{l}\text { TLFB (Time } \\
\text { Line Follow } \\
\text { Back), which } \\
\text { is done for } \\
90 \text { days. }\end{array}$ & $\begin{array}{l}\text { The significant effect } \\
\text { of the intervention } \\
\text { indicated that the CAMI } \\
\text { intervention could help } \\
\text { reduce unprotected } \\
\text { sexual intercourse. }\end{array}$ \\
\hline $\begin{array}{l}\text { Laurel P. } \\
\text { Gibson, } \\
\text { et al, } \\
2020 \text {, } \\
\text { Amerika } \\
\text { Serikat }\end{array}$ & $\begin{array}{l}\text { Randomized } \\
\text { Controlled } \\
\text { Trial }\end{array}$ & $\begin{array}{l}\mathrm{N}=156 r \\
\text { adolescents, }\end{array}$ & $\begin{array}{l}\text { Motivational Interviewing } \\
\text { (MI) and Behavioural } \\
\text { Skills Training (BST). }\end{array}$ & $\begin{array}{l}\text { TPB-based } \\
\text { Instrument }\end{array}$ & $\begin{array}{l}\text { Risky sexual behavior } \\
\text { decreased significantly } \\
\text { from the start }\end{array}$ \\
\hline $\begin{array}{l}\text { Pettifor, } \\
\text { Audrey et } \\
\text { al, 2015, } \\
\text { Malawi- } \\
\text { Afrika } \\
\text { Timur }\end{array}$ & $\begin{array}{l}\text { Randomized } \\
\text { Controll Trial }\end{array}$ & $\begin{array}{l}\mathrm{N}=27 \\
\text { adolescents }\end{array}$ & $\begin{array}{l}\text { Motivational Interviewing } \\
\text { (MI). Participants will } \\
\text { receive four sessions. } \\
\text { The three core } \\
\text { components that form the } \\
\text { basis of the intervention } \\
\text { and become the focus of } \\
\text { the counseling session } \\
\text { are understanding AHI, } \\
\text { increasing the client's } \\
\text { intrinsic motivation to } \\
\text { abstain. }\end{array}$ & - & $\begin{array}{l}\text { Very few participants } \\
\text { reported having } \\
\text { unprotected sex } \\
\text { after the intervention. } \\
\text { Participants reported a } \\
\text { tendency to have fewer } \\
\text { sex partners and not } \\
\text { have sex during the } \\
\text { follow-up study. }\end{array}$ \\
\hline $\begin{array}{l}\text { Sylvie } \\
\text { Naar- } \\
\text { King et } \\
\text { al, } 2012\end{array}$ & $\begin{array}{l}\text { Randomized } \\
\text { Clinical Trials }\end{array}$ & $N=100$ & $\begin{array}{l}\text { Motivational Interview. } \\
\text { The intervention } \\
\text { consisted of } 5 \text { weeks. } \\
\text { Individual counseling } \\
\text { sessions are } 90 \text { minutes } \\
\text { long followed by three } \\
\text { monthly booster sessions } \\
\text { of } 90 \text { minutes each. }\end{array}$ & $\begin{array}{l}\text { Motivational } \\
\text { Interviewing } \\
\text { Treatment } \\
\text { Integrity } \\
\text { codes (MITI). }\end{array}$ & 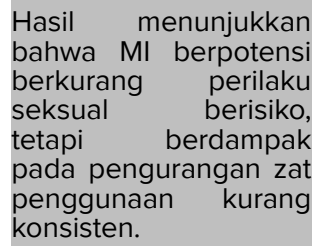 \\
\hline
\end{tabular}


Researchers in the United States, led by Peter M. Monti in 2016, found that the effects of motivational interviewing on sexual risk were comparable to those of alcohol in a sample of 184 participants. The intervention group reported fewer days of sexual intercourse under the influence of alcohol or drugs than the control group [9]. Melanie [5]conducted study in America found that the Counselor-Guided Motivational Intervention (CAMI) intervention had a substantial effect on reducing unprotected sexual intercourse among participants who completed the study. The CAMI intervention had a substantial effect in reducing unprotected sexual intercourse among participants who completed Gold's 2016 trial in America [5].

At a 3-month follow-up, Laurel P. Gibson's 2020 study, which was conducted in America with a sample of 262 adolescents, revealed that the intervention had a positive effect on risky sexual activity and condom usage. Risky sexual activity dropped considerably from baseline to follow; this decrease did not change according to the settings under which the study was conducted. The usage of condoms in the previous month, which is a component variable of the sex-risk index, increased considerably from baseline to follow-up across groups and did not differ by treatment condition, as previously reported [4]. Sylvie Naar-King [10] found that motivational interviewing can reduce risky sexual behavior. Future study with HIV-positive patients could include developing interventions that examine the influence of motivational interviewing on drug use [10]. According to Sylvie Naar [10] study, motivational interviewing therapies work through strengthening patient-provider communication and fostering client-centered behavior change to increase motivation and self-efficacy. Motivational interviewing is one of the most effective HIV interventions for adolescents [10]

\subsection{Results of assessment methodological quality}

The Randomized Control Trial (RCT) research have been classified as a high-quality study with a recommended grade of A according to the JBI grading system. Random number charts were utilized to generate allocations; allocation concealment was accomplished through the use of numbers on the charts. Each group was identified as experimental or control. Although blinding and loss to follow-up are not recorded properly, they do not create a danger of bias because the only measure is cost effectiveness. 


\section{Discussion}

Motivational interviewing is a client-centered counseling strategy that focuses on increasing intrinsic drive and promoting healthy behavior, particularly via the exploration and resolution of ambivalence [11]. Motivational interviewing is used to ascertain a client's readiness to engage in certain behaviors through the application of specific skills and tactics that respect the client's autonomy and facilitate client trust and decisionmaking [12]. According to [10], motivational interviewing interventions are effective in changing behavior because they establish a clear framework for improving providerclient communication and promoting client-centered behavior change with the goal of increasing motivation and self-efficacy [10].

The findings of this study corroborate those of [13], who found that motivational interviewing-based counseling can provide concrete examples of risk behavior reduction strategies and that the group receiving motivational interviewing-based interventions demonstrated increased risk behavior reduction skills [13]. Motivational interviewing is a type of counseling that use client-centered instructions to build intrinsic drive to change and to resolve ambivalence between present behavior and desired outcomes [14]. Additionally, therapy sessions are typically structured to facilitate behavior change through the use of a client-centered, nonjudgmental, and empathic approach [12].

The intervention used in this study consisted of five stages consistent with [15] theory, namely precontemplation, contemplation, preparation, action, and maintenance, where these stages can increase the effectiveness of motivational interviewing in resolving client problems [15]. The intervention was divided into three sessions in this study. The first session is precontemplation-contemplation, in which the client's concerns are brought to light and knowledge of the change possibilities discussed is increased. The second session is preparation-action, during which participants will establish action plans and commit to making changes. The third session is maintenance, during which the researcher assists the client in remaining focused on the behavior modification strategy.

Miller and Rollnick [16], on the other hand, defined four general concepts of motivational interviewing, namely: Empathy Expression. A counselor will demonstrate empathy, warmth, sincerity, and unconditional positive regard throughout a therapy session in order to establish a solid therapeutic relationship. Clients are encouraged to comprehend their own thoughts and attitudes through the use of skills such as listening, feeling understood, being thoughtful, and being active [17]. Create inconsistencies, particularly Counselors assist clients in expressing and describing their varied thoughts, feelings, 
and conflicts so that the client becomes aware of the disconnect between the client's wishes and the events that occurred [17]. Accept resistance, specifically Resistance is a regular occurrence during the transformation process. As a result, the client is adamant about not changing. Additionally, resistance is referred to as the outcome or outcome of the therapist's or counselor's encounter with the client. This principle demonstrates that the counselor must acknowledge all of the client's reluctance to change, but with the ability to reflect, the counselor can provide feedback by asking many views and recalling the client's prior statements regarding motivation to change. Accordingly, the counselor can provide subtle feedback in the form of confrontational (oppositional) remarks, arguments, and persuading. Additionally, the counselor can accept resistance while introducing fresh ideas for the client to consider, so leading the client down a different route [17]. Assisting with self-efficacy The counselor encourages and supports the client's belief in himself and his ability to change his life. The counselor demonstrates to the client that he or she is capable of completing and overcoming the task or obstacle. Counselors can repurpose change discourse and examine the client's commitment to change while promoting self-efficacy. The change in question is permanent, with full knowledge of the importance of other positive behavior adjustments [17].

\section{Conclusion}

It can be concluded that counseling combined with motivational interviewing is beneficial at reducing risky sexual behavior in teenagers and preventing HIV transmission. This study demonstrates that motivational interviewing counseling has an effect on lowering sexual behavior in adolescents, which is important in the prevention of HIV transmission.

\section{Conflict of interest}

The authors declare that they have no conflict of interest.

\section{Role of funding source}

This work was supported by STIKep PPNI Jawa Barat 2021. 


\section{References}

[1] Flickinger TE, Rose G, Wilson IB, et al. Motivational interviewing by HIV care providers is associated with patient intentions to reduce unsafe sexual behavior. Patient education and counseling,. 2013;93(1):122-9.

[2] Shafii T, Benson SK, Morrison DM. Brief motivational interviewing delivered by clinician or computer to reduce sexual risk behaviors in adolescents: Acceptability study. Journal of medical internet research. 2019;21(7):e13220.

[3] Miller WR, Rollnick S. Motivational interviewing: Helping people change. 3rd ed. New York: Guilford Press; 2013.

[4] Gibson LP, Gust CJ, Gillman AS, Bryan AD, Feldstein Ewing SW. Mechanisms of action for empirically supported interventions to reduce adolescent sexual risk behavior: $A$ randomized controlled trial. Journal Adolescent Health. 2020;67(1):53-60.

[5] Gold MA, Tzilos GK, Stein LAR, et al. A randomized controlled trial to compare computer-assisted motivational intervention with didactic educational counseling to reduce unprotected sex in female adolescents. Journal of Pediatric and Adolescent Gynecology. 2016;29(1):26-32.

[6] Starks TJ, Robles G, Pawson M, et al. Motivational interviewing to reduce drug use and HIV incidence among young men who have sex with men in relationships and are high priority for pre-exposure prophylaxis (Project PARTNER): Randomized controlled trial protocol. JMIR Res Protoc. 2019;8(7):13015.

[7] Apodaca TR, Magill M, Longabaugh R, Jackson KM, Monti PM. Effect of a significant other on client change talk in motivational interviewing. Journal of consulting and clinical psychology. 2013;81(1):35-46.

[8] Chen J, Li X, Xiong Y, Fennie KP, Wang H, Williams AB. Reducing the risk of HIV transmission among men who have sex with men: A feasibility study of the motivational interviewing counseling method. Nursing Health of Science. 2016;18(3):400-7.

[9] Monti PM, Mastroleo NR, Barnett NP, Colby SM, Kahler CW, Operario D. Brief motivational intervention to reduce alcohol and $\mathrm{HIV} /$ sexual risk behavior in emergency department patients: A randomized controlled trial. Journal of consulting and clinical psychology,. 2016;84(7):580-91.

[10] Naar-King S, Parsons J, Johnson A. motivational interviewing targeting risk reduction for people with HIV: A systematic review. Current HIV/AIDS Reports 9. 2012;9.

[11] Grodensky C, Golin C, Parikh MA, et al. Does the quality of safetalk motivational interviewing counseling predict sexual behavior outcomes among people living with 
HIV? Patient education and counseling. 2017;100(1):147-53.

[12] Salvo MC, Cannon-Breland ML. Motivational interviewing for medication adherence. Journal of the American Pharmacists Association. 2015;55(4):354-61.

[13] Pettifor A, Corneli A, Kamanga G, et al. HPTN 062: A pilot randomized controlled trial exploring the effect of a motivational-interviewing intervention on sexual behavior among individuals with acute HIV Infection in Lilongwe, Malawi. PLoS One. 2015;10(5):0124452.

[14] Harijanto W, Rudijanto A, Alamsyah A. Pengaruh konseling motivational interviewing terhadap kepatuhan minum obat penderita hipertensi. Jurnal Kedokteran Brawijaya. 2015;28:353-4.

[15] Cook PF, Bradley凶Springer L, Corwin MA. Motivational interviewing and HIV: Reducing risk, inspiring change. 2009;(Aug).

[16] Miller WR, Rollnick S. Motivational interviewing: Helping people change. Guilford Press; 2012.

[17] Erford BT. Teknik yang harus diketahui setiap konselor. Yogyakarta: Pustaka Pelajar. 